\title{
CAPTURE
}

\section{SEMIOSIS PROCESS IN THE SOUNDS OF GAMELAN AND PESINDEN IN SANDEKALA FILM}

\author{
Andri Albertha Pratama', Santosa Soewarlan ${ }^{2}$ \\ ${ }^{1}$ Politeknik Negeri Batam \\ ${ }^{2}$ Institut Seni Indonesia (ISI) Surakarta \\ E-mail: andri@polibatam.ac.id
}

\begin{abstract}
The research investigates the use of the sign (code) used by Amriy Ramadhan as the director when delivering messages through the sounds of 'gamelan' and 'pesinden' in the Sandekala film. Conflicts emerged when the signs that are used have broad interpretations for the audience. The signs are discribed and analyzed using the ten-sign classification analysis method from the Peirce semiotic trichotomy concept. This study shows the important meaning of the semiosis process of the distribution of other signs which in their presentation are interrelated to lead the audience's interpretation in the sounds of 'gamelan' and 'pesinden' presented in the Sandekala film. The using signs which the characteristic based are generally accepted convention such as non-verbal dialect (kinesics) can lead the audience's interpretation that the sound of 'gamelan' and 'pesinden' in the Sandekala film is a metonym of magical figure who has long hair, white dress based on the semiosis process of signs which are interrelated in the presentation of the narrative structure of the film with repeated indexical relationship patterns.
\end{abstract}

Keywords: Sandekala, Semiosis, Kinesics, Indexical, and Metonym

\begin{abstract}
ABSTRAK
Penelitian ini menyelidiki penggunaan tanda (kode) yang dipakai Amriy Ramadhan sebagai sutradara ketika menyampaikan pesan melalui suara gamelan dan pesinden dalam film Sandekala. Konflik muncul ketika tanda-tanda yang digunakan bisa saja memiliki ranah interpretasi yang luas bagi penonton. Tanda-tanda tersebut dideskripsikan dan dikaji menggunakan metode analisis klasifikasi sepuluh tanda dalam konsep trikotomi semiotika Peirce. Studi ini menunjukkan arti-pentingnya proses semiosis sebaran tanda-tanda lain yang dalam penyajiannya saling berelasi untuk menggiring interpretasi penonton terhadap suara gamelan dan pesinden yang disajikan dalam film Sandekala. Penggunaan tandatanda yang sifat dasarnya merupakan sebuah konvensi yang berlaku umum seperti bahasa non-verbal (kinesika) dapat mengarahkan interpretasi penonton bahwa suara gamelan dan pesinden pada film Sandekala adalah metonimi sosok gaib berambut panjang dan berbaju putih berdasarkan proses semiosis tanda-tanda yang saling berelasi dalam sajian struktur naratif film dengan pola hubungan indexical yang berulang.
\end{abstract}

Kata kunci: Sandekala, semiosis, kinesika, indexical, dan metonimi.

\section{PENDAHULUAN}

Sandekala merupakan sebuah film pendek ber-genre horor yang disutradarai oleh Amriy Ramadhan dan dibintangi oleh
Rizka Dwi Septiana dan Kesyia Safalina.

Film Sandekala yang diproduksi oleh Snap

Films diadaptasi dari keyakinan masyarakat perkotaan tentang misteri 
senja atau yang dikenal sebagai sandekala.

Film Sandekala menjadi pemenang Film Pendek Favorit Pilihan di XXI Short Film Festival 2016. Film ini juga sudah diputar di Los Angeles Indonesian Film Festival pada tahun 2015.

Sinopsis film Sandekala berpusat pada seorang ibu dan putrinya yang menemui peristiwa supranatural ketika mereka hendak pulang pada saat pergantian hari dari terang ke gelap atau yang dikenal sebagai sandekala. Saat mereka melewati lorong jalan yang sepi, sesuatu mengintai dan mengikuti mereka.

Amriy Ramadhan menyisipkan suara gamelan dan pesinden dalam salah satu adegan filmnya tersebut. Suara gamelan dan pesinden yang disajikan dalam film ini sangat erat hubungannya dengan unsur kebudayaan Jawa. Kedua unsur tersebut sering digunakan dalam pertunjukan kesenian Jawa seperti wayang, kethoprak, uyon-uyon, dan pengiring tari klasik. Hal ini akan menjadi sangat menarik ketika suara gamelan dan pesinden tersebut dihubungkan dengan peristiwa magis yang menjadi mitos dalam masyarakat yang dikemas dalam sebuah sajian film bergenre horor. Suara digunakan dalam film untuk meningkatkan suasana hati, menunjukkan lokasi adegan, menjalankan plot, dan menunjukkan karakter dalam cerita (Sugihartono \& Wibawa, 2019).

Suara gamelan dan pesinden yang disisipkan dalam salah satu adegan film Sandekala tidak hanya bertujuan untuk menghadirkan salah satu bentuk kesenian Jawa yang dikemas dalam sebuah tembang/gending. Akan tetapi melalui unsur-usur ini sutradara ingin menyampaikan pesan-pesan lain yang dikodifikasikan (encoded) kepada penonton melalui sebuah narasi yang diciptakan dengan melibatkan kedua unsur berupa suara gamelan dan pesinden.

Tujuan penelitian ini adalah (1) untuk mengungkapkan dan mendeskripsikan tanda-tanda yang digunakan filmmaker dalam membangun narasi film untuk menyampaikan pesannya yang dikodekannya berupa suara gamelan dan pesinden, dan (2) mengkaji proses semiosis yang terjadi pada sistem tanda tersebut menggunakan metode analisis klasifikasi sepuluh tanda dalam konsep Trikotomi Semiotika Peirce sehingga peneliti dapat mengetahui alasan mengapa Amriy Ramadhan memilih kode-kode (tanda) tersebut untuk mewakili pesan yang disampaikannya.

\section{TINJAUAN PUSTAKA}

Hasil riset yang berkaitan dengan penelitian ini telah dilakukan oleh Ayu Mella Angelina dengan judul Film Fiction "Tuan X": Gestur Approach As A Psychology Mark of A Main Figure, membahas tentang karya film yang berhasil menggunakan gestur untuk menunjukkan gambaran psikologis dari tokoh. Gestur yang tepat 
dapat didukung dengan pengulangan gerakan untuk memperkuat sebuah karakter tokoh, sehingga intensitas ketegangan cerita dalam mencapai klimaks sesuai dengan genre yang diangkat (Angelina, Abidin, \& Karyadi, 2018).

Penelitian oleh Muhammad Yunus Patawari dengan judul Analysis of $X$ Generation in Film Turah membahas tentang pemaknaan relasi serta konflik antar generasi yang terjadi dalam masyarakat pada film Turah, bagaimana karakter tokoh-tokoh dalam film tersebut mewakili generasinya masing-masing menggunakan pendekatan analisis shot Christian Metz (M. Y. Patawari, 2018).

Film merupakan sebuah teks yang tersusun dari tanda-tanda yang saling berhubungan. Ini sesuai dengan gagasan teori yang membuat sebuah model sistematis dalam menganalisis proses semiosis dari tanda-tanda melalui analisis tanda. Dengan model sistematis tersebut kita tidak hanya mengetahui apa isi pesan yang hendak disampaikan oleh sutradara, melainkan kita juga dapat mengetahui bagaimana pesan itu dibuat, dan tandatanda apa saja yang digunakan untuk mewakilinya melalui film yang disampaikan kepada khalayak.

Retensi memori film dalam eksperimen yang dilakukan oleh Bruce, Fraisse dan De Monmollin, Rébeillard, atau Romano dan Bolton - semuanya sampai pada kesimpulan yang sama, meskipun ditempuh dengan cara yang berbeda: yang berkesan dalam sebuah film adalah plotnya dan beberapa gambar (Metz, 1991).

Kode selalu menjadi bahan pembicaraan dalam Semiotika. Kode merupakan hubungan logis yang memungkinkan sebuah pesan dapat dipahami. Kode tidak ada dalam film, namun kode merupakan aturan-aturan yang mengatur pesan dalam sebuah film. Mereka sebenarnya adalah konstruksi semiotik yang dibangun oleh para ahli Semiotika setelah mempelajari sejumlah film, dan merumuskannya (kode-kode) dalam film-film tersebut. Dengan demikian kode memiliki keberadaan nyata tetapi bukan keberadaan fisik. Kode adalah kebalikan dari material ekspresi. Mereka adalah bentuk-bentuk logis yang dimasukkan ke dalam material ekspresi untuk menghasilkan pesan (Andrew, 1976).

Sutradara film menggunakan kode untuk membuat materialnya berbicara kepada penonton, sedangkan semiotik bekerja dari arah yang berlawanan, yakni menggunakan pesan-pesan film tersebut untuk membantunya menyusun kode-kode yang melampaui pesan-pesan itu. Sebagian besar diskusi film dan kritik film berkonsentrasi pada apa yang dikatakan film (pesan). Namun, semiotik fokus pada hukum yang mengatur pesan-pesan itu. Semiotik tidak ingin mengulangi apa yang sudah dikatakan teks (film). Namun, semiotik bertujuan untuk memisahkan 
semua mekanisme logis yang memungkinkan bahan mentah film untuk berbicara atau menyampaikan pesanpesan tersebut (Andrew, 1976).

Sistem semiosis dibangun dari kode yang diberikan oleh sutradara melalui film yang dibuatnya. Semiolog membangun sistem semiosis-nya dengan cara menemukan dan menghubungkan semua kode yang ada di dalam film. Sebagai contoh, semiologis yang tertarik akan kode yang berupa akting, maka dalam proses semiosis-nya harus memperhatikan banyak sistem di mana kode akting itu berperan. Dalam hal ini akting merupakan satu kode yang terkait dan berhubungan dengan kode-kode yang lain seperti kerja kamera, pengeditan, pencahayaan, dan kode nonspesifik yang tak terhitung jumlahnya dalam subjek yang difilmkan (Andrew, 1976).

Metz berpendapat bahwa shot adalah unit terkecil dari rantai film (yang lain menyebutnya "taxeme," seperti istilah yang digunakan oleh Hjelmslev); dan sekuen adalah keseluruhan sintagmatik yang lebih besar (Metz, 1991). Shot dalam penelitian ini merupakan unsur sinematik yang menjadi perhatian khusus karena di dalamnya terdapat kode-kode yang saling ber-semiosis dalam menyampaikan pesan pembuat film kepada penonton.

Selain unsur sinematik, naratif merupakan unsur yang tak terpisahkan dalam membangun hubungan semiosis kode-kode yang tersebar. Naratif atau yang sering juga disebut narasi adalah proses menceritakan peristiwa yang meliputi cerita nyata maupun fiktif. Fungsi naratif dalam sinema adalah bercerita/mendongeng bukan deskripsi. Narasi mengacu pada strategi, kode, dan konvensi (termasuk mise-en-scène dan pencahayaan) yang digunakan untuk mengatur cerita (Hayward, 2001). Unsur sinematik dan naratif dalam film merupakan dua unsur yang saling melengkapi satu sama lainnya.

Kesan (impresi) realitas yang dialami oleh penonton adalah satu hal yang tidak kalah pentingnya dari banyak masalah yang ada pada teori film. Film memberi kita perasaan bahwa kita sedang menyaksikan tontonan yang hampir nyata. Kesan yang diperoleh dari menyaksikan sebuah film melebihi dari apa yang dapat diberikan oleh karya seni lain seperti novel, drama, atau lukisan figuratif. Hal ini dikarenakan film dapat melepaskan mekanisme partisipasi afektif dan persepsi pada diri penonton (Metz, 1991).

Peirce mengembangkan sistem paralel petanda (signifiers) dan penanda (signifieds) Saussure, berdasarkan pada tiga set hubungan antara tanda yang dikenal dengan model triadic dan konsep trikotominya yang terdiri atas tanda atau sign (representamen), objek (object), dan interpretan (interpretant). Hubungan dari ketiganya yang dikombinasikan untuk membentuk sistem tanda yang dapat 


\section{CAPTURE}

menghasilkan kelas trikotomi yang membingungkan dan sangat rumit.

Trikotomi pertama sign

Sign (representamen), adalah tanda (representamen) atau tanda yang didasarkan pada hubungan tanda dengan yang pertama hadir di dalam suatu hubungan triadic murni dengan yang kedua, yang disebut object-nya, sehingga mampu menentukan yang Ketiga, yang disebut sebagai interpretant-nya (Peirce \& Buchler, 2012).

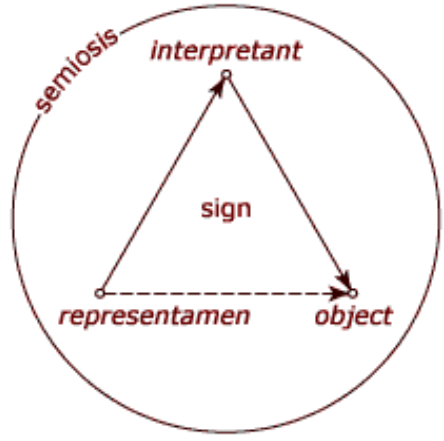

Gambar 1. Model Triadic Semiosis Peirce (Sumber: https://cseweb.ucsd.edu)

Peirce juga membagi tanda berdasarkan relasi dengan object dan interpretant ke dalam tiga kelompok. Ketiga kelompok itu berkaitan dengan pembedaan mendasar Peirce mengenai tiga kategori eksistensial: ke-pertama-an (firstness), kekedua-an (secondness), ke-ketiga-an (thirdness) (Zoest, 1993).

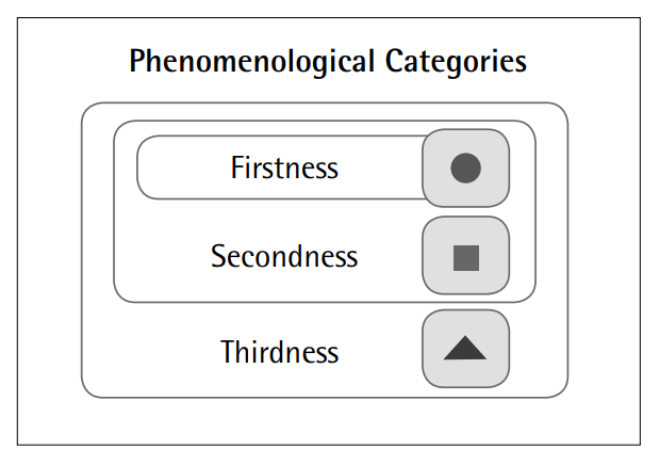

Gambar 2. Klasifikasi Kelas Tanda (Sumber: Borges, 2010) sifat ground-nya, dibagi menjadi qualisign, sinsign, dan legisign. Qualisign adalah tanda yang merupakan tanda berdasarkan suatu sifat. Sinsign adalah tanda yang merupakan tanda atas dasar tampilnya dalam kenyataan. Legisign adalah tandatanda yang merupakan tanda atas dasar suatu peraturan yang berlaku umum, konvensi, atau kode (Zoest, 1993).

Trikotomi kedua, tanda didasarkan dengan objeknya (denotatum), dibagi menjadi icon (ikon), indexical (indeks), dan symbol (simbol). Ikon adalah tanda ada sebagai kemungkinan, tanpa tergantung pada objeknya, namun dapat dikaitkan atas dasar suatu persamaan yang secara potensial dimilikinya. Indeks adalah sebuah tanda yang tergantung dari adanya sebuah denotatum baik berupa fisik, temporal maupun indeks atau petunjuk sebuah peristiwa (sebab-akibat). Simbol (lambang) adalah tanda yang hubungan antara tanda dan denotatum-nya ditentukan oleh suatu peraturan yang berlaku umum (Zoest, 1993).

Tanda indeksikal adalah efek yang memungkinkan kita untuk menyimpulkan suatu sebab. Tanda indeksikal bisa berupa audio maupun visual. Penonton sebuah film memiliki kebebasan untuk menginterpretasikan setiap tanda (Butler, 2008). 
Trikotomi ketiga adalah tanda yang didasarkan pada interpretant-nya. Pada Trikotomi ini tanda dibagi menjadi tiga yaitu, rheme, dicisign (dicent signs), dan argument. Tanda merupakan rheme bila dapat diinterpretasikan sebagai representasi dari suatu kemungkinan denotatum. Sebuah tanda merupakan sebuah dicisign, bila bagi interpretant-nya, tanda itu menawarkan hubungan yang benar ada di antara tanda terhadap denotatum-nya. Tanda yang bagi intrepretant-nya merupakan tanda yang berlaku umum disebut sebagai argument. Bila dalam hubungan tanda interpretatif, tanda itu tidak dianggap sebagai bagian dari suatu kelas, maka tanda ini merupakan sebuah argument (Zoest, 1993).

Tabel 1. Trikotomi Tanda Peirce

\begin{tabular}{cccc|}
\hline & Firstness & $\begin{array}{c}\text { Secondnes } \\
\text { s }\end{array}$ & Thirdness \\
$\begin{array}{c}\text { Representa } \\
\text { men }\end{array}$ & Qualisign & Sinsign & Legisign \\
\hline $\begin{array}{c}\text { (O) } \\
\text { Object } \\
\text { (I) }\end{array}$ & Icon & Indexical & Symbol \\
Interpretant & Rheme & Dicent & Argument \\
\hline
\end{tabular}

Peirce menurunkan sepuluh kelas tanda dari logika kategori fenomenologisnya. Dengan demikian, jika konstituen pertama trikotomi adalah sifat pertama, itu hanya dapat menentukan hubungan kategori ini. Jika konstituen pertama trikotomi ada, yang merupakan sifat kedua, maka konstituen kedua dapat menentukan hubungan hanya kemungkinan (pertama) atau keberadaan (kedua). Akhirnya, jika dasar dari tanda adalah hukum (ketiganya), hubungan antara tanda dan objeknya bisa menjadi salah satu kemungkinan (pertama), keberadaan (kedua), atau hukum (ketiga) (Borges, 2010).

Sepuluh kelas tipologi tanda dihasilkan dengan cara melakukan kombinasi sebuah unsur dari pembagian tiga pasal yang sudah disampaikan sebelumnya dengan dua unsur lainnya dari trikotomi yang ada. Berikut sepuluh kelas tanda dan uraiannya secara singkat:

a. Sebuah qualisign. Seharusnya secara lengkap disebut: qualisign iconic, rhematic, tetapi karena setiap qualisign juga harus merupakan sebuah icon dan sebuah rheme, maka kata-kata sifatnya tidak perlu disebutkan. Contoh: sifat 'merah'.

b. Sebuah sigsign iconic. Selalu merupakan sebuah rheme. Contoh: Labu yang dapat mirip kepala seseorang negarawan.

c. Sinsign indexical rhematic. Contoh: sebuah jeritan spontan yang menarik perhatian sesuatu.

d. Sebuah sinsign dicent. Selalu indexical. Contoh: sebuah petunjuk arah angin.

e. Sebuah legisign iconic. Selalu merupakan sebuah rheme. Contoh: sebuah diagram batang, tanpa ada tanda lain (symbol). 


\section{CAPTURE}

f. Sebuah legisign indexical rhematic. Contoh: sebuah kata deiktis ('disini', 'kini') terlepas dari suatu konteks atau situasi.

g. Sebuah legisign indexical dicent. Contoh: suara tukang es di jalan.

h. Sebuah symbol rhematic. Selalu merupakan sebuah legisign. Contoh: sebuah kata benda, terlepas dari suatu konteks atau situasi.

i. Sebuah symbol dicent. Selalu merupakan sebuah legisign. Peirce juga menyebutnya sebagai proposisi biasa. Contoh: sebuah kalimat.

j. Sebuah argument. Selalu merupakan symbol dan legisign. Contoh: sebuah bentuk tanda majemuk seperti sebuah sajak, sebuah roman, sebuah silogisme (Zoest, 1993).

Afinitas dari sepuluh kelas ditampilkan dengan mengatur penunjukan mereka dalam tabel segitiga yang ditampilkan pada Tabel 2, yang memiliki batas berat antara kotak yang berdekatan yang disesuaikan dengan kelas yang sama hanya dalam satu hal. Semua kotak yang berdekatan lainnya berkaitan dengan kelas yang sama dalam dua hal. Kuadrat tidak berdekatan berkaitan dengan kelas sama dalam satu hal saja, kecuali bahwa masingmasing dari tiga kuadrat dari simpul segitiga berkaitan dengan kelas yang berbeda dalam ketiga hal dari kelas, di mana kuadrat di sepanjang sisi yang berlawanan dari segitiga tersebut disesuaikan. Tulisan yang dicetak ringan tidak berguna, karena kata-kata sifatnya tidak perlu disebutkan.

Tabel 2. Sepuluh Kelas Tipologi Tanda Peirce

(Sumber: Peirce \& Buchler, 2012)

\begin{tabular}{|c|c|c|c|c|c|}
\hline \multirow{2}{*}{$\begin{array}{c}\text { (I) } \\
\text { Rhematic } \\
\text { Iconic }\end{array}$} & \multicolumn{2}{|c|}{ (V) } & \multicolumn{2}{|c|}{ (VIII) } & $(\mathrm{X})$ \\
\hline & \multicolumn{2}{|c|}{ Rhematic } & Rhematic & Symbol & $\begin{array}{c}\text { Argument } \\
\text { Symbol }\end{array}$ \\
\hline Qualisign & \multicolumn{2}{|c|}{ Legisign } & & sign & Legisign \\
\hline & & & & & $(\mathrm{IX})$ \\
\hline \multirow{3}{*}{\multicolumn{2}{|c|}{$\begin{array}{c}\text { Rhematic } \\
\text { Iconic } \\
\text { Signsin }\end{array}$}} & \multirow{2}{*}{\multicolumn{2}{|c|}{$\begin{array}{l}\text { Rhematic } \\
\text { Indexical }\end{array}$}} & \multicolumn{2}{|c|}{ Dicent } \\
\hline & & & & & $\mathrm{mbol}$ \\
\hline & & \multicolumn{2}{|c|}{ Legisign } & \multicolumn{2}{|c|}{ Legisign } \\
\hline & \multicolumn{3}{|c|}{ (III) } & \multicolumn{2}{|l|}{ (VII) } \\
\hline & \multicolumn{3}{|c|}{ Rhematic } & \multicolumn{2}{|c|}{ Dicent } \\
\hline & \multicolumn{3}{|c|}{ Indexical } & \multicolumn{2}{|c|}{ ndexical } \\
\hline & \multicolumn{3}{|c|}{ Sinsign } & \multicolumn{2}{|c|}{ Legisign } \\
\hline & \multicolumn{5}{|c|}{ (IV) } \\
\hline & \multicolumn{5}{|c|}{ Dicent } \\
\hline & \multicolumn{5}{|c|}{ Indexical } \\
\hline & \multicolumn{5}{|c|}{ Sinsign } \\
\hline
\end{tabular}

Sepuluh kelas tipologi tanda ini juga dapat digambarkan dalam gambar diagram pohon sebagai berikut.

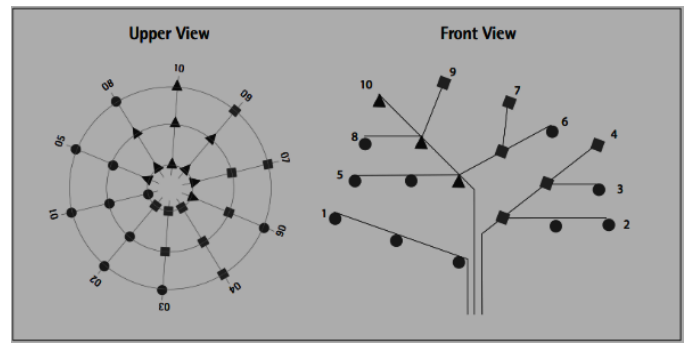

Gambar 3. Signtree Model (10 Classes) (Sumber: Borges, 2010)

Amriy banyak menggunakan bahasa non verbal untuk menyampaikan pesannya pada penonton film ini, sehingga penelitian ini juga merujuk pada idiom umum tentang bahasa tubuh yang disampaikan oleh 
Hanifah Raah bahwa bahasa tubuh lebih umum daripada yang dipikirkan. Banyak ungkapan dan idiom yang kita gunakan dalam dialog sehari-hari, memiliki makna yang lebih dalam yang merujuk pada bahasa tubuh tersebut (Raah, 2015).

\section{METODE}

Penelitian ini tidak berkonsentrasi pada apa yang-dikatakan oleh film (pesan) seperti hasil penelitian terdahulu yang pernah dikaji baik dari tesis maupun penelitian lainnya, namun penelitian ini berfokus pada sebaran kode-kode (tanda) yang di-decode dari pesan film itu sendiri, serta mendeskripsikan bagaimana hubungan semiosis-nya. Hal ini akan menegaskan bahwa penelitian ini bukan sebuah penelitian tentang wacana atau kritis film.

Penelitian ini berfokus pada proses semiosis tanda suara gamelan dan pesinden dalam film Sandekala, sesuai dengan judul yang sudah disampaikan peneliti di awal. Penelitian ini diawali dengan mendeskripsikan struktur naratif yang disajikan dalam film Sandekala. Hal ini guna merumuskan pesan apa yang ingin disampaikan oleh pembuat film terkait suara gamelan dan pesinden yang dikemas dalam salah satu adegan di dalam film ini. Dalam hal ini, pesan merupakan hasil mediasi film yang mengubah wujud segala bentuk substansi film yang sebelumnya masih berada di dalam ranah konsep dan ide-ide (Santosa, 2011).
Berpedoman pada pesan yang merupakan hubungan antara tanda dan objeknya (pesan), maka peneliti fokus pada sebaran kode-kode (tanda) yang mengacu pada objek tersebut. Dengan mengurai kode/tanda (decode), peneliti mendeskripsikan proses-proses semiosis dalam sistem tanda yang terjalin pada sebaran tanda-tanda tersebut. Dengan begitu, peneliti akan mengetahui alasan mengapa Amriy Ramadhan memilih kodekode (tanda) tersebut untuk mewakili pesan yang akan disampaikannya.

Berdasarkan proses semiosis tanda pada pesan gamelan dan pesinden tersebut, maka tanda dapat diklasifikasi berdasarkan tipologi tanda dengan model triadic yang dikembangkan oleh Charles Senders Peirce. Tipologi tanda ini terdiri atas representamen (sign), object dan interpretant yang keberadaannya dibedakan dalam kelas trikotomi (trichotomies) yaitu membagi tanda atas 3 tingkatan dan 9 sub tipe tanda. Pada umumnya klasifikasi tanda yang digunakan dalam analisis Semiotika adalah sifat hubungan tanda terhadap objeknya, yaitu ikon, indeks, dan simbol. Akan tetapi untuk mendapatkan hasil analisis yang lebih mendalam, maka peneliti akan menggunakan semua tingkatan tanda dari trikotomi pertama, kedua, dan ketiga beserta komponennya untuk mendapatkan hasil yang maksimal. 


\section{CAPTURE}

\section{PEMBAHASAN}

\subsection{Visualisasi Tanda dalam Film Sandekala}

Film Sandekala menceritakan tentang peristiwa supranatural yang terjadi di penghujung senja (magrib). Kepercayaan masyarakat Indonesia pada saat magrib, para makhluk gaib sedang berkeliaran menculik anak-anak dan mengganggu aktivitas mereka. Film ini menggambarkan peristiwa supranatural bermula saat seorang ibu dan putrinya melewati lorong jalan yang sepi. Mereka mulai merasakan sesuatu sedang mengintai dan mengikuti mereka.

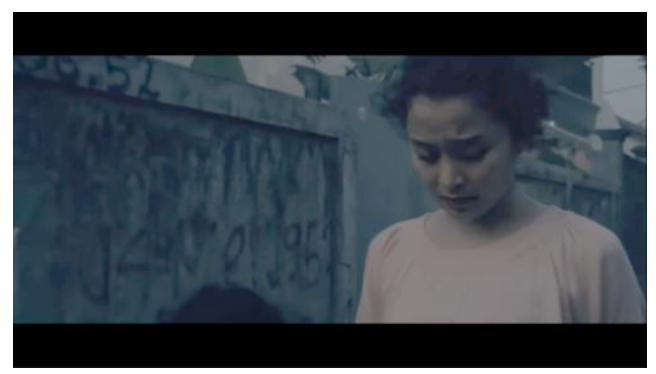

Gambar 1. Seorang ibu yang sedang khawatir dalam perjalanan pulang (Sumber: Film Sandekala, 2015, TC: 00:01:03)

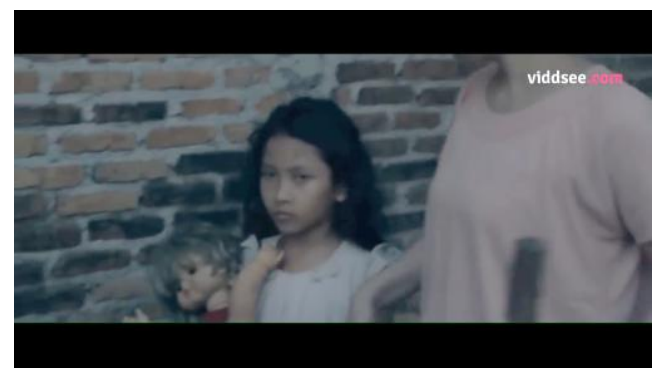

Gambar 2. Putrinya yang juga merasa khawatir saat dalam perjalanan pulang

(Sumber: Film Sandekala, 2015, TC: 00:01:14)

Ibu tersebut terhenti sejenak, menunduk dan sedikit menoleh ke belakang setelah angin menerpa wajah dan rambutnya, hal ini menandakan sang ibu yang saat itu merasakan kehadiran sesuatu. Lalu ibu mengangkat kepalanya, menoleh ke kanan sambil memejamkan matanya sembari menghembuskan nafas dari hidung secara perlahan. Ini menandakan sang ibu yang merasa khawatir akan kehadiran sesuatu pada saat angin menerpa wajahnya. Namun, karena hari sudah mulai malam, maka mereka tetap melanjutkan perjalanannya dengan perasaan khawatir.

Adegan selanjutnya menggambarkan anak perempuan kecil yang sedang bersama ibu tersebut turut merasakan kegelisahan. Hal ini ditunjukkan dalam adegan anak kecil yang memperhatikan sekelilingnya dan mengamati lahan kosong tidak terawat yang berada di sebelah kiri mereka. Lahan kosong yang tidak terawat tersebut menjadi penanda bahwa tempat ini menjadi hunian yang disukai makhluk gaib.

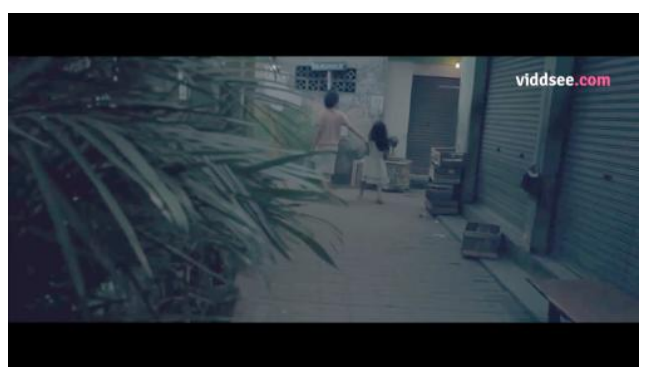

Gambar 3. Si anak berhenti sambil menarik dan menahan tangan ibunya.

(Sumber: Film Sandekala, 2015, TC: 00:01:32)

Adegan berikutnya anak perempuan ini menarik dan menahan tangan ibunya, yang menandakan bahwa dia tidak ingin melalui jalan yang biasa 
mereka tempuh. Bahasa non verbal ini juga diterima dengan maksud yang sama oleh si ibu. Hal ini ditunjukkan pada adegan selanjutnya yaitu si ibu bertanya "loh kenapa, biasanya kan kita lewat sini ?"

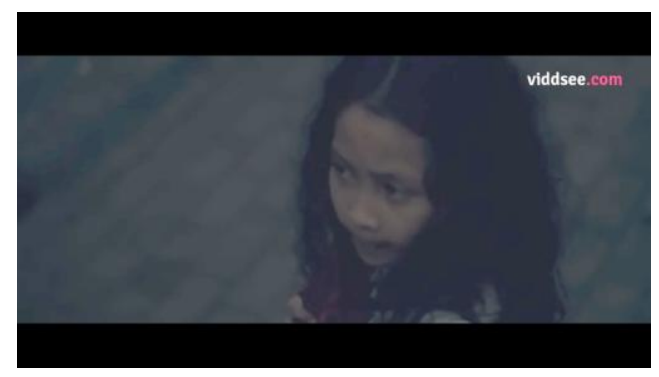

Gambar 4. Melihat ke arah lorong, lalu melihat si ibu sembari menggelengkan kepala. (Sumber: Film Sandekala, 2015, TC: 00:01:39)

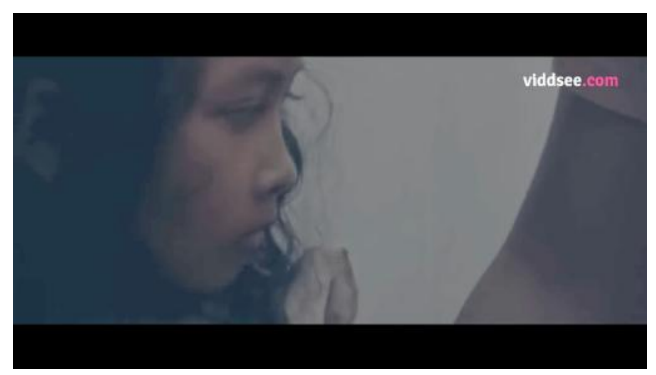

Gambar 5. Melihat ke belakang (arah lorong). (Sumber: Film Sandekala, 2015, TC: 00:02:16)

Pertanyaan yang diutarakan si ibu dijawab oleh si anak dengan melihat ke arah lorong, lalu melihat si ibu sembari menggelengkan kepala. Melihat ke lorong merupakan petanda bahwa si anak merasakan adanya kehadiran sesuatu di lorong tersebut, dan melihat si ibu sembari menggelengkan kepala merupakan petanda menolak ajakan si ibu yang didasarkan rasa khawatir akan sesuatu yang ada pada lorong tersebut. Penolakan si anak dipenuhi oleh si ibu dengan menganggukkan kepalanya. Menganggukkan kepala merupakan petanda ungkapan persetujuan akan tindakan yang terjadi sebelumnya.

Tanda yang dihadirkan melalui tingkah si anak tidak hanya satu kali. Saat mereka mulai kebingungan karena jalan lorong yang mereka lalui hanya berputarputar di tempat itu saja. Si anak sesekali melihat ke belakang (arah lorong) yang merupakan petanda bahwa si anak merasakan kehadiran sesuatu di lorong tersebut. Perasaan khawatir dan takut juga ditunjukkan oleh si ibu pada adegan selanjutnya.

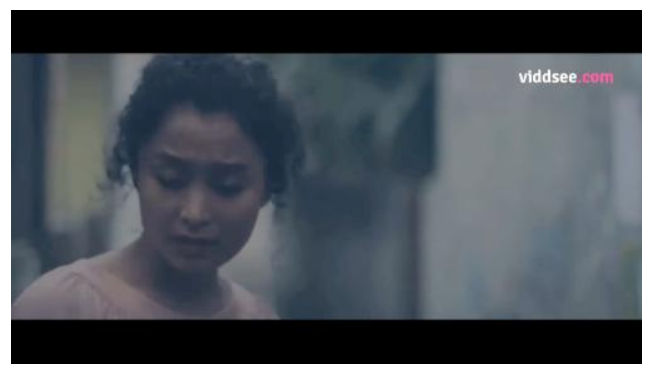

Gambar 6. Memperhatikan sekeliling dan merasakan takut.

(Sumber: Film Sandekala, 2015, TC: 00:02:35)

Si ibu memperhatikan sekeliling dan melihat si anak dengan mimik muka berupa kerutan dahi, pergerakan alis dan tatapannya yang menandakan sedang merasakan takut.

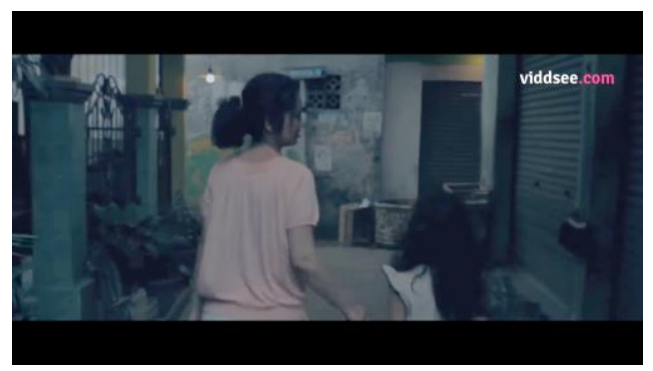

Gambar 7. Si ibu pasrah karena merasa kesal dengan apa yang mereka alami. (Sumber: Film Sandekala, 2015, TC: 00:03:21) 


\section{CAPTURE}

Si ibu menyerah dan pasrah ditunjukkan pada adegan dengan gerakan bahasa tubuh menurunkan bahu dan lengan dengan cara melemaskan tubuh dan tangannya sambil menatap persimpangan jalan tempat mereka kembali dengan kerutan dahi dan tatapannya. Bahasa tubuh ini merupakan petanda bahwa si ibu menyerah dan pasrah dengan apa yang mereka tengah alami. Sesekali si ibu menghentakkan kakinya sebagai petanda rasa kesal atas apa yang dirasakannya.

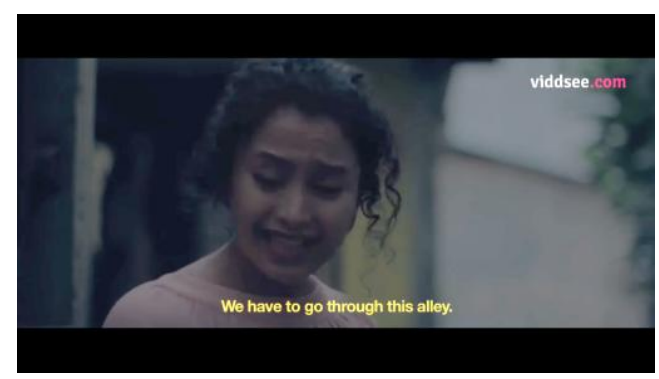

Gambar 8. Si ibu mengajak anaknya untuk melalui jalan lorong yang biasanya mereka lalui.

(Sumber: Film Sandekala, 2015, TC: 00:03:28)

Adegan berikutnya si ibu mengajak anaknya untuk melalui jalan yang biasanya mereka lalui. Si ibu mengatakan "kita harus lewat sini !" merupakan petanda bahwa si ibu sudah menyerah dan menolak untuk mencoba melewati jalan lorong yang lain. Petanda yang lain untuk tanda yang sama, melalui pernyataan tersebut si ibu meyakinkan kepada anaknya bahwa tidak ada jalan lain yang bisa ditempuh.

Ajakan si ibu tidak disetujui oleh si anak. Si anak bergerak mundur dan menarik tangan si ibu menandakan bahwa si anak menolak dan tidak mau melalui jalan lorong yang biasa mereka lalui.

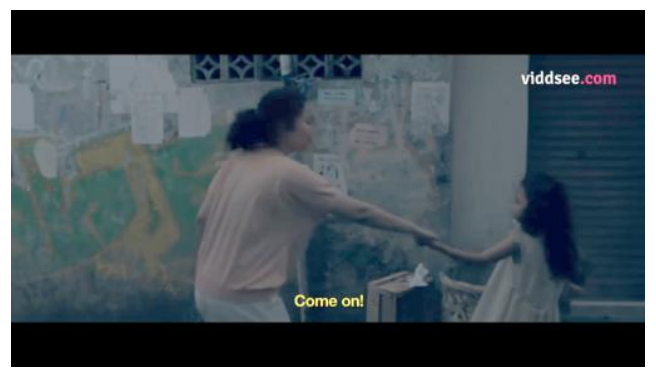

Gambar 9. Si anak menolak ajakan si ibu untuk melalui jalan lorong yang biasanya mereka lalui. (Sumber: Film Sandekala, 2015, TC: 00:03:29)

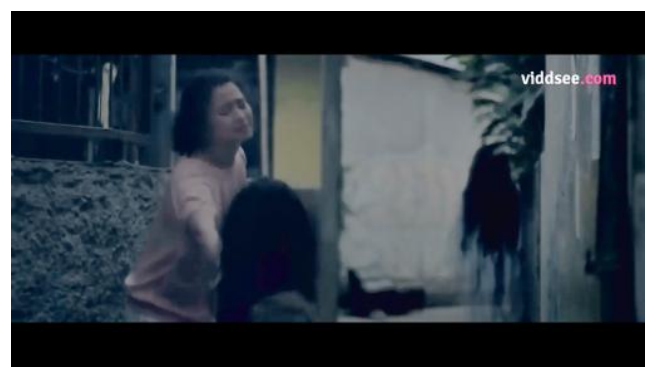

Gambar 10. Penampakan wanita berambut panjang dan berbaju putih di lorong jalan. (Sumber: Film Sandekala, 2015, TC: 00:03:30)

Perasaan khawatir si anak akan kehadiran sesuatu pada lorong tersebut akhirnya terjawab. Kejadian supranatural yang mereka alami sebelumnya, akhirnya ditunjukkan dengan tanda-tanda yang lebih nyata. Adegan ini memperlihatkan penampakan sosok berambut panjang dan berbaju putih yang terlihat oleh si anak di lorong jalan yang akan mereka lalui merupakan petanda bahwa adanya kehadiran sosok lain yang mengintai, mengikuti bahkan mengganggu mereka.

Adegan selanjutnya, saat akan melalui lorong jalan yang sempit, langkah mereka terhenti karena mendengar suara gamelan. Si anak menyembunyikan wajahnya dengan mendekap tangan kanan 
ibunya merupakan petanda bahwa si anak merasa khawatir dan takut akan terdengarnya suara gamelan tersebut.

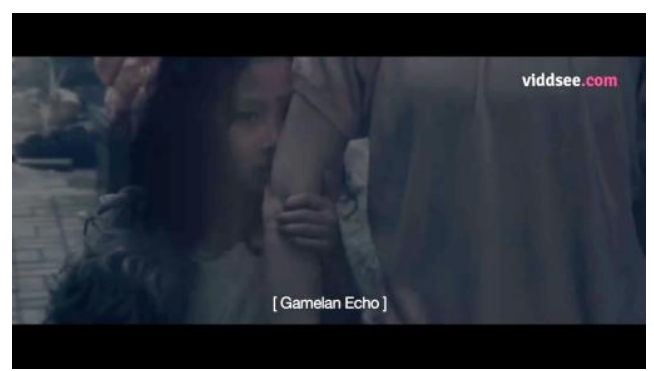

Gambar 11. Si anak menyembunyikan wajahnya saat terdengar suara gamelan (Sumber: Film Sandekala, 2015, TC: 00:03:47)

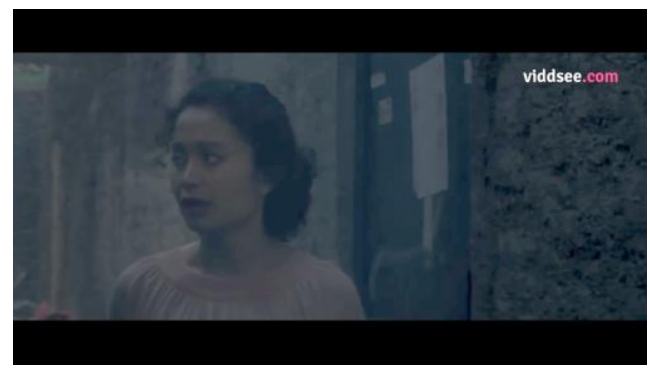

Gambar 12. Si ibu menoleh ke belakang saat suara gamelan terdengar semakin jelas.

(Sumber: Film Sandekala, 2015, TC: 00:03:51)

Si ibu menoleh ke arah belakang secara perlahan menjadi sebuah petanda bahwa sumber suara tersebut berasal dari belakang mereka. Si ibu menoleh ke arah belakang setelah mendengar suara gamelan juga menandakan bahwa si ibu khawatir dan takut sehingga ingin memastikan apa yang sedang terjadi di belakang mereka. Hal ini merupakan petanda bahwa si ibu merasa khawatir dan takut setelah mendengar suara gamelan tersebut. Perasaan takut pada adegan ini sangat berelasi dengan penampakan sosok gaib yang terjadi sebelumnya. Tanda-tanda yang ditunjukkan oleh ekspresi si ibu sekaligus menjadi petanda untuk memastikan apakah sosok yang muncul sebelumnya sedang berada di belakang mereka. Namun, si ibu hanya melihat gumpalan asap yang datang dari arah lorong yang telah mereka lalui. Gumpalan asap juga merupakan sebuah tanda karena munculnya asap pada momen-momen tertentu sering dihubungkan dengan hal-hal yang berbau mistis atau sesuatu yang gaib.

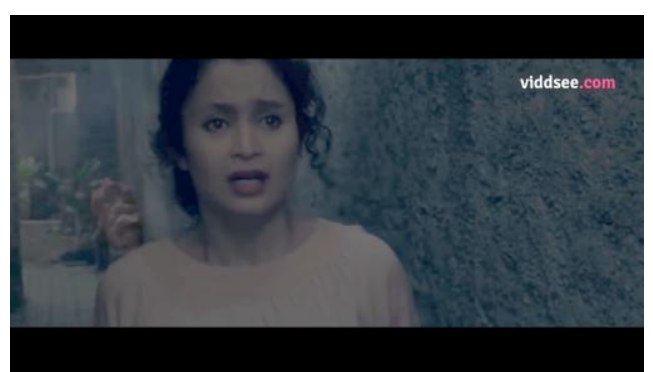

Gambar 13. Si ibu terkejut dan takut saat lorong yang mereka lalui bergerak menjauh.

(Sumber: Film Sandekala, 2015, TC: 00:04:41)

Mereka segera melanjutkan perjalanan dengan tergesa-gesa menuju ujung lorong sesaat setelah kejadian tersebut. Ketika berjalan mendekati ujung lorong, ujung lorong tersebut bergerak menjauh. Untuk kedua kalinya mereka berjalan menuju ujung lorong, namun ujung lorong tersebut menjauh lagi. $\mathrm{Si}$ ibu berhenti, melotot dan menghela nafas dari mulutnya merupakan petanda bahwa si ibu sangat terkejut dan takut atas kejadian tersebut. Ujung lorong yang bergerak menjauh merupakan petanda bahwa kejadian yang mereka alami pada saat itu tidaklah lazim. Hal ini serupa dengan kejadian sebelumnya saat jalan lorong 


\section{CAPTURE}

yang mereka lalui hanya berputar-putar di tempat itu saja.

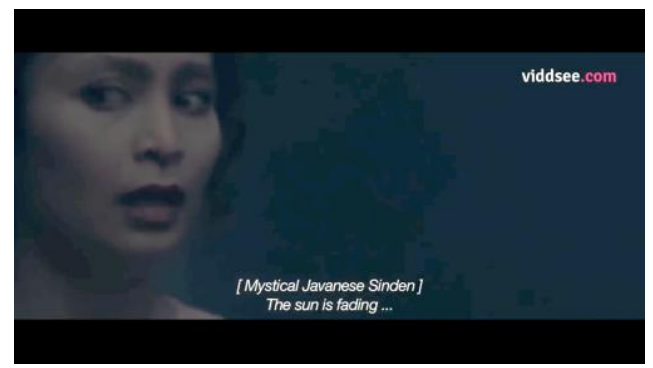

Gambar 14. Si ibu terkejut dan takut saat mendengar suara pesinden bernyanyi.

(Sumber: Film Sandekala, 2015, TC: 00:05:02)

Peristiwa-peristiwa supranatural ini terus dirasakan oleh ibu dan putrinya. Saat mereka mencoba berjalan perlahan melalui ujung lorong yang semakin menjauh. Saat yang bersamaan, mereka mendengar suara pesinden yang sedang bernyanyi. $\mathrm{Si}$ ibu menghela nafas melalui mulut, melotot lalu melirik ke arah belakang dengan perlahan merupakan petanda bahwa si ibu terkejut dan merasa takut akan kehadiran suara nyanyian pesinden tersebut. Melirik ke arah belakang secara perlahan dan memperhatikan sekelilingnya juga merupakan tanda untuk memastikan apa yang ada di belakangnya. Hal ini serupa dengan tindakan yang dilakukannya saat mendengar suara gamelan sebelumnya untuk memastikan apakah sosok yang muncul sebelumnya sedang berada di belakang mereka.

Berikut adalah kutipan lirik yang dinyanyikan oleh pesinden:

"Srengenge ampun langite mendhak, ampun kesah. ampun ajrih, kula badhe ngancani kula enten nipun mriki, kula enten nipun mriki, kula badhe ngancani, kula pun nipun mriki". ["Matahari sudah memudar, jangan pergi, jangan takut, saya akan menemani, saya sudah ada di sini, saya sudah ada di sini, saya akan menemani, saya sudah di sini".] (Film Sandekala, 2015, Timecode: 00:05:03)

Dari kutipan lirik dan terjemahannya ke dalam Bahasa Indonesia yang dinyanyikan oleh pesinden dalam adegan tersebut merupakan petanda bahwa adanya kehadiran sosok lain dalam adegan tersebut yang tidak dapat dilihat oleh si ibu dan anaknya.

\subsection{Proses Semiosis dalam Film}

\section{Sandekala}

Hasil analisis penelitian diawali dengan mengklasifikasikan tanda-tanda (kode) yang sudah disampaikan di atas. Tanda-tanda tersebut diklasifikasikan berdasarkan sepuluh kelas tipologi tanda yang dilihat berdasarkan; hubungan tanda terhadap sifat ground-nya, berikutnya hubungan tanda terhadap sifat denotatumnya, dan yang terakhir adalah hubungan tanda dengan interpretan-nya.

Penelitian ini fokus pada proses semiosis suara gamelan dan pesinden dalam menyampaikan pesan sutradara. Penjelasan proses semiosis gamelan dan pesinden dalam film ini, tahapannya dimulai dari proses semiosis dalam sebaran tanda-tanda yang terjadi sebelum adegan suara gamelan dan pesinden dalam film Sandekala. Hal ini dikarenakan proses semiosis tanda-tanda tersebut 
berikutnya membentuk beberapa sistem tanda yang akhirnya dapat mempengaruhi dan membentuk struktur naratif dalam sebuah film. Pemahaman yang didapatkan oleh penonton setelah menonton film ini, nantinya dapat dijadikan pedoman atau pegangan bagi mereka yang sebelumnya melihat bentuk substansi film ini masih dalam bentuk keyakinan-keyakinan yang berada di dalam ranah konsep atau ide-ide di alam "awang-awang" (Santosa, 2011).

Sebaran tanda yang pertama adalah petanda mengenai perasaan khawatir dan takut akan kehadiran sesuatu yang mengintai dan mengikutinya. Si ibu terhenti sejenak, merunduk dan sedikit menoleh ke belakang lalu mengangkat kepalanya, menoleh ke kanan sambil menghembuskan nafas dari hidung. Si anak menarik dan menahan tangan ibunya. $\mathrm{Si}$ anak menjawab pertanyaan ibunya dengan melihat ke lorong sembari menggelengkan kepala. Mereka mulai kebingungan karena jalan lorong yang mereka lalui hanya berputar-putar di tempat itu saja. Si anak sesekali melihat ke belakang (arah lorong). Si ibu yang memperhatikan sekeliling dan melihat si anak dengan mimik muka berupa kerutan dahi, pergerakan alis dan caranya menatap. Tanda-tanda di atas merupakan tanda yang hadir dalam sebuah sistem tanda bahasa tubuh. Maka tanda-tanda ini merupakan legisign indexical rhematic karena tanda yang disampaikan berupa tanda (kinesika) yang memiliki hubungan sebab akibat dari suatu kemungkinan denotatum-nya (khawatir dan takut).

Sebaran tanda yang kedua adalah petanda penampakan sosok makhluk gaib berambut panjang dan berbaju putih. Penampakan sosok berambut panjang dan berbaju putih merupakan sinsign symbol rematic, karena tanda tersebut tanda atas dasar tampilnya (terlihat) berupa konvensi yang berlaku umum untuk menyatakan tanda (sosok berambut panjang dan berbaju putih yang muncul secara tiba-tiba) dari suatu kemungkinan denotatum-nya (sosok gaib).

Sebaran tanda yang ketiga adalah petanda kehadiran sosok lain (sosok gaib)yang mengintai, mengikuti bahkan mengganggu mereka. Si anak bergerak mundur dan menarik tangan si ibu setelah melihat sosok berambut panjang dan berbaju putih. Tanda ini merupakan legisign indexical dicent karena tanda yang disampaikan berupa tanda bahasa yang memiliki hubungan sebab akibat yang benar ada di antara tanda (kinesika) dan denotatum-nya (rasa khawatir dan takut akan munculnya sosok gaib). Tanda ini juga sekaligus menjadi jawaban atas kekhawatiran dan takut yang mereka alami pada adegan-adegan sebelumnya.

Sebaran tanda yang keempat adalah suara gamelan dan pesinden. Suara gamelan dan pesinden yang terdengar dalam adegan film Sandekala 
merupakan proses semiosis legisign indexical dicent, karena tanda tersebut berupa konvensi yang berlaku umum untuk menyatakan hubungan yang benar ada antara tanda (suara gamelan dan pesinden) dan denotatum-nya (alat musik gamelan dan pesinden).

Sebaran tanda yang kelima adalah petanda perasaan khawatir dan takut saat terdengar suara gamelan. Si anak menyembunyikan wajahnya dengan mendekap tangan kanan ibunya. Si ibu menoleh ke arah belakang secara perlahan. Nafasnya yang terengah-engah, kerutan dahi, lirikan mata secara perlahan ke arah belakang. Berikutnya petanda yang sama untuk suara pesinden, si ibu menghela nafas melalui mulut, melotot lalu melirik ke arah belakang dengan perlahan. Si ibu melirik ke arah belakang secara perlahan dan memperhatikan sekelilingnya. Mereka berlari kencang meninggalkan lorong dan berusaha tidak menghiraukan apa yang terjadi. Tanda ini merupakan legisign indexical dicent karena tandatanda (kinesika) yang disampaikan di atas berupa tanda bahasa yang memiliki hubungan sebab akibat yang benar ada di antara tanda dan denotatum-nya (rasa khawatir dan takut akan terdengarnya suara gamelan dan pesinden). Sistem tanda ini juga merupakan proses semiosis legisign indexical dicent yang serupa seperti proses semiosis yang terjadi antara tanda (kinesika) dan denotatum-nya (rasa khawatir dan takut akan munculnya sosok gaib) di atas.

Proses semiosis sebaran tanda yang di-encode oleh Amriy memiliki kesamaan dalam pola pemilihan tandatandanya. Coba perhatikan lima proses semiosis yang sudah dibahas sebelumnya:

a. Legisign indexical rhematic (kinesika $\rightarrow$ perasaan khawatir dan takut).

Kinesika merupakan tanda (reperesentamen) yang hadir dalam sebuah sistem tanda bahasa tubuh. Karena kinesika merupakan suatu Bahasa, maka menurut klasifikasi representamen yang telah dibuat oleh Peirce didasari pada hubungan tanda terhadap ground-nya, maka kinesika adalah representamen dalam kategori thirdness yaitu legisign.

Proses semiosis hubungan tanda (kinesika) terhadap denotatum-nya (perasaan khawatir dan takut) merupakan tanda yang tergantung dari adanya sebuah denotatum yang berupa indeks atau petunjuk dari peristiwa yang mengakibatkan perasan khawatir dan takut. Karena perasaan khawatir dan takut merupakan indeks atau petunjuk dari sebuah peristiwa, maka menurut klasifikasi object yang telah dibuat oleh Peirce berdasarkan hubungan tanda terhadap denotatum-nya, perasaan khawatir dan takut adalah object dalam kategori secondness 
yaitu indexical.

Proses semiosis berikutnya adalah hubungan tanda (kinesika) yang didasarkan pada interpretant-nya (perasaan khawatir dan takut akan kehadiran sesuatu yang mengintai dan mengikuti mereka) merupakan tanda yang diinterpretasikan sebagai representasi dari suatu kemungkinan denotatum. Karena "sesuatu yang mengikuti mereka" masih merupakan suatu representasi dari suatu kemungkinan, maka menurut klasifikasi interpretant yang telah dibuat oleh Peirce berdasarkan hubungan tanda terhadap interpretantnya, perasaan khawatir dan takut akan kehadiran sesuatu yang mengintai dan mengikuti mereka adalah interpretant dalam kategori firstness yaitu rhematic.

b. Sigsign symbol rhematic (sosok berambut panjang dan berbaju putih yang muncul secara tiba-tiba $\rightarrow$ sosok gaib).

Sosok berambut panjang dan berbaju putih yang muncul secara tiba-tiba merupakan tanda (reperesentamen) yang hadir nyata dan dapat dilihat sebagai sebuah tanda. Karena sosok berambut panjang dan berbaju putih yang muncul secara tiba-tiba merupakan tanda atas dasar tampilnya dalam kenyataan, maka menurut klasifikasi representamen yang telah dibuat oleh Peirce yang didasari pada hubungan tanda terhadap ground-nya, sosok berambut panjang dan berbaju putih yang muncul secara tiba-tiba adalah representamen dalam kategori secondnes yaitu sinsign.

Proses semiosis hubungan tanda (sosok berambut panjang dan berbaju putih yang muncul secara tiba-tiba) terhadap denotatum-nya (sosok gaib) merupakan tanda yang hubungan antara tanda dan denotatum-nya ditentukan oleh sesuatu yang berlaku secara umum. Karena sosok berambut panjang dan berbaju putih merupakan sesuatu yang berlaku secara umum untuk menunjukkan sosok gaib, maka menurut klasifikasi object yang telah dibuat oleh Peirce berdasarkan hubungan tanda terhadap denotatumnya, sosok gaib adalah object dalam kategori thridness yaitu symbol.

Proses semiosis berikutnya adalah hubungan tanda (sosok berambut panjang dan berbaju putih yang muncul secara tiba-tiba) yang didasarkan pada interpretant-nya (sosok yang menakutkan dan berbahaya) merupakan tanda yang diinterpretasikan sebagai representasi dari suatu kemungkinan denotatum. Karena "sosok yang menakutkan dan berbahaya" masih merupakan suatu representasi dari suatu kemungkinan, 


\section{CAPTURE}

maka menurut klasifikasi interpretant yang telah dibuat oleh Peirce berdasarkan hubungan tanda terhadap interpretant-nya, sosok yang menakutkan dan berbahaya adalah interpretant dalam kategori firstness yaitu rhematic.

c. Legisign indexical dicent (kinesika $\rightarrow$ rasa khawatir dan takut akan munculnya sosok gaib).

Kinesika merupakan tanda (reperesentamen) yang hadir dalam sebuah sistem tanda bahasa tubuh. Karena kinesika merupakan suatu bahasa, maka menurut klasifikasi representamen yang telah dibuat oleh Peirce didasari pada hubungan tanda terhadap ground-nya, kinesika adalah representamen dalam kategori thirdness yaitu legisign.

Proses semiosis hubungan tanda (kinesika) terhadap denotatum-nya (rasa khawatir dan takut akan munculnya sosok gaib) merupakan tanda yang tergantung dari adanya sebuah denotatum yang berupa indeks atau petunjuk dari peristiwa yang disebabkan oleh munculnya sosok gaib. Karena kinesika merupakan indeks atau petunjuk dari sebuah peristiwa rasa khawatir dan takut akan munculnya sosok gaib, maka menurut klasifikasi object yang telah dibuat oleh Peirce berdasarkan hubungan tanda terhadap denotatum- nya, rasa khawatir dan takut akan munculnya sosok gaib adalah object dalam kategori secondness yaitu indexical.

Proses semiosis berikutnya adalah hubungan tanda (kinesika) yang didasarkan pada interpretant-nya (sosok gaib yang muncul secara tibatiba adalah sosok menakutkan dan berbahaya) merupakan hubungan yang benar ada di antara tanda dan denotatum-nya. Karena "sosok yang muncul secara tiba-tiba adalah sosok yang menakutkan dan berbahaya" merupakan hubungan yang benar ada di antara tanda (kinesika) terhadap denotatum-nya (rasa khawatir dan takut akan munculnya sosok gaib), maka menurut klasifikasi interpretant yang telah dibuat oleh Peirce berdasarkan hubungan tanda terhadap interpretant-nya, sosok yang muncul secara tiba-tiba adalah sosok yang menakutkan dan berbahaya merupakan interpretant dalam kategori secondness yaitu dicent.

d. Legisign indexical dicent (suara gamelan dan pesinden $\rightarrow$ alat musik gamelan dan pesinden).

Suara gamelan dan pesinden merupakan tanda (reperesentamen) yang hadir dalam sebuah sistem tanda yang berlaku umum (seperti itulah suara gamelan (bonang) saat di bunyikan dan suara pesinden saat 
melantunkan sebuah tembang). Karena suara gamelan dan pesinden merupakan tanda yang berlaku umum, maka menurut klasifikasi representamen yang telah dibuat oleh Peirce didasari pada hubungan tanda terhadap ground-nya, suara gamelan dan pesinden adalah representamen dalam kategori thirdness yaitu legisign. Proses semiosis hubungan tanda (suara gamelan dan pesinden) terhadap denotatum-nya (alat musik gamelan dan pesinden) merupakan tanda yang tergantung dari adanya sebuah denotatum yang berupa indeks atau petunjuk dari peristiwa yang disebabkan oleh adanya alat musik gamelan dan pesinden. Karena gamelan dan pesinden merupakan indeks atau petunjuk dari suara gamelan dan pesinden yang terdengar, maka menurut klasifikasi object yang telah dibuat oleh Peirce berdasarkan hubungan tanda terhadap denotatum-nya, gamelan dan pesinden adalah object dalam kategori secondness yaitu indexical.

Proses semiosis berikutnya adalah hubungan tanda (suara gamelan dan pesinden) yang didasarkan pada interpretant-nya (alat musik gamelan (bonang) yang sedang dimainkan dan pesinden yang sedang melantunkan sebuah tembang) merupakan hubungan yang benar ada di antara tanda dan denotatum-nya. Karena "alat musik gamelan yang sedang dimainkan dan pesinden yang sedang melantunkan sebuah tembang" merupakan hubungan yang benar ada di antara tanda (suara gamelan dan pesinden) terhadap denotatum-nya (alat musik gamelan dan pesinden), maka menurut klasifikasi interpretant yang telah dibuat oleh Peirce berdasarkan hubungan tanda terhadap interpretant-nya, alat musik gamelan yang sedang dimainkan dan pesinden yang sedang melantunkan sebuah tembang adalah interpretant dalam kategori secondness yaitu dicent.

e. Legisign indexical dicent (kinesika $\rightarrow$ rasa khawatir dan takut akan terdengarnya suara gamelan dan pesinden).

Kinesika merupakan tanda (reperesentamen) yang hadir dalam sebuah sistem tanda bahasa tubuh. Karena kinesika merupakan suatu bahasa, maka menurut klasifikasi representamen yang telah dibuat oleh Peirce didasari pada hubungan tanda terhadap ground-nya, kinesika adalah representamen dalam kategori thirdness yaitu legisign.

Proses semiosis hubungan tanda (kinesika) terhadap denotatum-nya (suara gamelan dan pesinden) merupakan tanda yang tergantung dari 
adanya sebuah denotatum yang berupa indeks atau petunjuk dari peristiwa yang disebabkan oleh terdengarnya suara gamelan dan pesinden. Karena kinesika merupakan indeks atau petunjuk dari sebuah peristiwa rasa khawatir dan takut akan terdengarnya suara gamelan dan pesinden, maka menurut klasifikasi object yang telah dibuat oleh Peirce berdasarkan hubungan tanda terhadap denotatum-nya, rasa khawatir dan takut akan terdengarnya suara gamelan dan pesinden adalah object dalam kategori secondness yaitu indexical.

Proses semiosis berikutnya adalah hubungan tanda (kinesika) yang didasarkan pada interpretant-nya (suara gamelan dan pesinden yang tiba-tiba terdengar tanpa adanya wujud fisik keberadaan alat musik gamelan dan pesinden) merupakan hubungan yang benar ada diantar tanda dan denotatum-nya. Karena "suara gamelan dan pesinden yang terdengar tiba-tiba tanpa adanya wujud fisik keberadaan alat musik gamelan dan pesinden" merupakan hubungan yang benar ada di antara tanda (kinesika) terhadap denotatumnya (rasa khawatir dan takut akan terdengarnya suara gamelan dan pesinden), maka menurut klasifikasi interpretant yang telah dibuat oleh
Peirce berdasarkan hubungan tanda terhadap interpretant-nya suara gamelan dan pesinden yang terdengar tiba-tiba tanpa adanya wujud fisik keberadaan alat musik gamelan dan pesinden adalah interpretant dalam kategori secondness yaitu dicent.

Hasil dari lima proses semiosis di atas dapat disimpulkan bahwa Amriy lebih memilih tanda-tanda yang bersifat konvensi seperti kinesika, suara gamelan dan pesinden yang berlaku secara umum untuk menyampaikan pesannya melalui film. Hal ini dimungkinkan agar pesan yang diterima oleh penonton setelah menyaksikan film ini sama seperti apa yang direncanakannya.

\section{SIMPULAN}

Film yang merupakan sebuah teks yang tersusun dari tanda-tanda yang sarat dengan makna untuk menyampaikan pesan dari si pembuat film kepada penonton. Film horor Sandekala dengan tema mitos sangat erat hubungannya dengan kehidupan masyarakat Indonesia. Film Sandekala mengungkapkan bagaimana peristiwa supranatural yang dialami oleh seorang ibu dan putrinya ketika mereka hendak pulang pada saat pergantian hari dari terang ke gelap (sandekala).

Konsep yang diterapkan pada film ini telah berhasil memberikan tanda untuk mencapai makna pesan yang ingin disampaikan sineas. Bahasa non verbal (kinesika) yang berupa pergerakan tubuh 
(gesture) dan mimik muka tokoh dalam menjadi peran penting dalam menyampaikan pesan pembuat film kepada penonton. Kinesika menjadi tanda (legisign) kunci yang utama untuk menyampaikan pesan rasa khawatir dan takut akan sesuatu yang awalnya belum diketahui. Selanjutnya rasa khawatir dan takut dijadikan alasan dari yang disebabkan oleh sebuah objek (symbol) berupa sosok gaib.

Pemilihan suara latar berupa bunyi gamelan dan pesinden dalam Bahasa Jawa sangat memberikan warna dalam film tersebut, sehingga penonton semakin merasakan dekatnya budaya Jawa dalam film tersebut dengan kehidupan sehari-hari. Pemilihan suara gamelan dan pesinden sebagai sebuah tanda bukanlah tidak beralasan. Suara gamelan dan pesinden dipilih karena memiliki sifat tanda yang sama seperti kinesika yaitu tanda yang bersifat legisign. Hal ini dimungkinkan agar pesan-pesan yang disampaikan oleh tanda-tanda tersebut melalui adegan dalam film ini sesuai dengan apa yang diharapkan oleh sutradara.

Suara gamelan dan pesinden pada film ini merupakan metonimi sosok berambut panjang dan berbaju putih pada timecode 00:03:30. Proses encode-nya suara gamelan dan pesinden dihadirkan sebagai metafora sosok gaib dengan cara menunjukkan ciri-ciri yang sama pada konteks proses semiosis yang terjadi di antara keduanya. Suara gamelan dan pesinden sebagai metafora sosok gaib dalam film ini adalah dibentuk melalui proses semiosis yang tercipta dari tandatanda yang saling membangun dalam mempengaruhi dan membentuk struktur naratif dalam film ini. Penggunaan beberapa efek suara angin dan suara latar dengan frequency tertentu membuat film ini semakin menyeramkan untuk ditonton.

\section{DAFTAR ACUAN}

Andrew, D. (1976). The Major Film Theories: An Introduction. London; New York: Oxford University Press.

Angelina, A. M., Abidin, Z., \& Karyadi, FX. Y. (2018). Film Fiction "Tuan X": Gestur Approach As A Psychology Mark of A Main Figure. CAPTURE: Jurnal Seni Media Rekam, 10(1), 14-26.

https://doi.org/10.33153/capture.v1 $0 \mathrm{i} 1.2186$

Borges, P. (2010). A Visual Model of Peirce's 66 Classes of Signs Unravels His Late Proposal of Enlarging Semiotic Theory. Dalam Model-Based Reasoning in Science and Technology (Vol. 314).

Butler, A. M. (2008). Film Studies. Harpenden: Pocket Essentials.

Hayward, S. (2001). Cinema Studies: The Key Concepts (Second). Taylor \& Francis E-Library.

Metz, C. (1991). Film Language: $A$ Semiotics of the Cinema. Chicago: University of Chicago Press.

Patawari, M. Y. (2018). Analysis of $X$ Generation in Film Turah. CAPTURE: Jurnal Seni Media Rekam, 10(1), 1-13. https://doi.org/10.33153/capture.v1 $0 \mathrm{i} 1.2197$ 
Peirce, C. S., \& Buchler, J. (2012). Philosophical Writings of Peirce. Diambil dari https://books.google.co.id/books?id $=$ De7DAgAAQBAJ

Raah. (2015). Body Language: 101: Discover the Psychology Secrets of How to Read and Understand Non Verbal Communication and Always Be One Move Ahead. Axiom Core Publishing.

Santosa. (2011). Komunikasi Seni: Aplikasi dalam Pertunjukan Gamelan. Surakarta: ISI Pers Surakarta.

Sugihartono, R. A., \& Wibawa, A. (2019). Editing: Film, Televisi, dan Animasi. Yogyakarta: Graha IImu.

Zoest, A. van. (1993). Semiotika: Tentang Tanda, Cara Kerjanya dan Apa Yang Kita Lakukan Dengannya. Jakarta: Yayasan Sumber Agung. 